\title{
NOTES
}

\section{A MAP OF WHITMAN'S WASHINGTON BOARDING HOUSES AND WORK PLACES}

On the back cover of this issue of the Walt Whitman Quarterly Review is a map, designed by Emery Pajer, that shows the locations of seven boarding houses in downtown Washington, D.C., where Walt Whitman lived between the years 1863 and 1873 . The list, compiled from correspondence and annual city directories, represents the most complete listing to date of residences that can be verified. I have also included Whitman's work places on the map. In addition to his wartime service as a nurse, Whitman held three Federal jobs, working as a clerk in progressively more responsible positions.

Whitman moved to the capital at a time of a severe housing shortage. $\mathrm{He}$ was lucky to find decent housing at all in wartime Washington. And yet he tended to move every year, each move usually corresponding to a visit to his family in Brooklyn; he would give up one place for the month or so he was gone and move into a new house on his return. This had the practical effect of saving him a month's rent each year. I believe it also suited Whitman's temperament to move often: boarding house life surrounded the poet with people yet allowed him to retain a sense of reserve, not threatening him with the demands of too much intimacy. For someone simultaneously scared of, and yearning for, a deep connection to others-what his friend Nelly O'Connor called an "elusive disposition" - Whitman's transient boardinghouse lifestyle might have served as a form of emotional armor as well.

Most addresses below are given in two versions, because the street numbering system in Washington changed after 1870 . Modern city addresses are regularized in a grid pattern: for example, the 300 block of L Street is located between $3^{\text {rd }}$ and $4^{\text {th }}$ Streets. Prior to 1870 , however, buildings were numbered as they were erected without regard to the cross streets, so I have "translated" all pre-1870 addresses. None of the houses, unfortunately, still stand.

\section{Residences}

\section{394 L Street North. Now the site of the American Medical Associa- tion, entrance at 1101 Vermont Ave. NW. Whitman moved here in Janu- ary 1863.}

Whitman's first Washington address was in the same house as his friends William and Nelly O'Connor. The O'Connors occupied two rooms on the third floor, for which, Whitman noted, they paid "the extraordinary price of $\$ 25$ a month. I have a werry little bedroom on the $2 \mathrm{~d}$ floor," which he rented for seven dollars a month. ${ }^{2}$ 
The O'Connors shared Whitman's working-class background. William was a novelist who worked as a clerk for the Light-House Board (then a part of the Treasury Department). Nelly had previously worked in a factory, and as a governess and school teacher. When Whitman met her, she was finally middleclass enough to be able to stay home with her children, but Whitman moved in while she was still in mourning for her son Philip, who had died at two years old of smallpox. An older daughter, Jeannie, was five when Whitman joined their household. Whitman seems to have filled an emotional void for Nelly after Philip's death.

The owner of the house was Mr. Carey Gwynne, whom Whitman disparaged as "a mixture of booby, miser \& hog." 3 The double front doors were outfitted with multiple locks and bolts, and Whitman complained that "we were well fortified I tell you-sometimes I had an awful time at night getting in." 4

\section{2. $4566^{\text {th }}$ Street West. Now the site of the U.S. Securities and Exchange Commission, entrance at $4156^{\text {th }}$ St. NW. Whitman moved here in Oc- tober 1863.}

After Gwynne sold his house, the O'Connors and Whitman were forced to move. Whitman's new location was close enough to the O'Connors that he could continue to eat supper with them daily. Whitman's second Washington home was a three-story structure owned by Mrs. Eliza S. Baker, a widow raising her granddaughter. Whitman's attic room had a southern exposure and he was the only boarder. He noted the extra privacy in a letter to his mother, as well as a sunny side yard with grass and trees that provided "sweet \& good air." ${ }^{5}$ Whitman paid ten dollars a month.

\section{502 Pennsylvania Avenue. Now part of the U.S. Capitol grounds, on a triangle of land across from the reflecting pool at the base of Capitol Hill. Whitman moved here in May 1864.}

Whitman described the conditions of this third Washington address as "miserable," but he liked its proximity to the Capitol and Armory Square Hospital. $\mathrm{He}$ ate his meals with other boarders, dining with the O'Connors only on Sundays and holidays. Most Washingtonians believed that homes closer to the Mall, at lower elevations than the rest of the city, were less healthy. These properties were also subject to seasonal flooding from the canal that ran along what is today Constitution Avenue. While living at this address, Whitman began complaining of spells of faintness and headaches, which he attributed to the "very bad air" of his lodgings. ${ }^{6}$ It is more likely, of course, that his health problems were related to his volunteer nursing duties. When Whitman moved out, he took an extended vacation with his mother in Brooklyn to rest and recover, from the end of June through the end of January 1865. 


\section{468 M Street South. Now the Claridge Tower Apartments, entrance at 1221 M St. NW. Whitman moved here in January 1865.}

In contrast to his previous address, Whitman considered this neighborhood "the healthiest, sweetest part of Washington."7 Whitman's landlords, Edward and Juliet Grayson, were Southern sympathizers, and their son was in the Confederate army. He described the landlady: "she is so different from any I found yet here, is very obliging, starts my fire for me at 5 o'clock every afternoon, \& lights the gas, even, \& then turns it down to be ready for me when I come home." ${ }^{8} \mathrm{He}$ paid $\$ 32.50$ a month for a "good big bed" and "very good grub." While living here, Whitman met Peter Doyle on the Washington and Georgetown horsecar, where Doyle was working as a fare collector.

\section{5. $36413^{\text {th }}$ Street West. Now a multistory office building, entrance at 1220 L St. NW. Whitman moved here in February 1866.}

When the war ended, the city changed drastically. Whitman complained in a letter to Alfred Pratt, a former soldier he had nursed, "Washington is rather dull-no more soldiers around like there used to be-no more patrols marching in the streets-no more great racks of hospitals-I get along well enough in this city in pleasant weather, when one can go around, but it's rough in bad weather." 10

\section{472 M Street South. Now the site of the Claridge Tower Apartments. Whitman moved here sometime in 1867.}

Just two doors down from his previous lodgings in the Grayson home, Whitman found a large new house with a "tip-top table" 11 and several other boarders, "mostly young people, full of life \& gayety." 12 The landlady, Mrs. Newton Benedict, worked for the Treasury, and like Whitman, came from New York. Mrs. Benedict employed African American servants to handle the cooking and cleaning for her boarders. Whitman stayed here through midJuly 1870, at which time he returned to New York for approximately three months, while he saw three books through the printing process: the fifth edition of Leaves of Grass, Passage to India, and Democratic Vistas.

After this point, we lose touch with Whitman until 1873. By this time, all of his correspondence came to his work place (a more stable address), and he had begun listing himself in the city directory at his business as well.

\section{7. $53515^{\text {th }}$ Street NW. Now the site of the Hotel Washington, entrance at $51515^{\text {th }}$ St. NW. It is unclear when Whitman moved to this, his final DC home.}

Whitman rented an attic room in this boarding house, directly across the street from the Treasury Building, where he was then working. Whitman often stayed at the office in the evenings to avoid his poorly heated room. $\mathrm{He}$ reported to his mother, "I spend a good deal of time, evenings \& Sundays, in the office at my desk, as I can get into the Treasury building any time, as the 
door-keepers all know me-nearly all of them are broken down or one-legged soldiers-The office is warm \& nice, with gas, \& all the modern improvements." 13

It was in his office, alone, late at night, where Whitman suffered his paralyzing stroke on January 23, 1873. He managed to drag himself down the office stairs and the few hundred feet to his boarding house, then up the stairs to his bed, but later that night he awoke and realized he couldn't move his legs. A doctor was called the next morning and, although he did rally somewhat, Whitman was never really well again. At first Peter Doyle and another friend, Charles Eldridge, took turns staying with Whitman during the days and nights, "helping \& lifting \& nursing me," as he reported to his mother. ${ }^{14}$ But as a full recovery began to seem more remote, Whitman realized he would have to make other plans.

Although Whitman came to D.C. with no intention to stay, once there he seems to have had no intention of leaving either. Whitman considered these ten years the most significant period of his life. Had it not been for his stroke, which necessitated his move to Camden, New Jersey, Whitman might well have stayed in Washington permanently.

\section{Work Places}

\section{Federal office building, $15^{\text {th }}$ and F Streets NW. Now the site of the Hotel Washington. Whitman worked in a building at this site twice, from 1863 to 1864 , and from 1865 to 1871 .}

In Whitman's first job for the Paymaster General, he had a $5^{\text {th }}$ floor office with "a splendid view, away down south, of the Potomac river, and across to the Georgetown side, and the grounds and houses of Washington spread out beneath my high point of view." 15

In his third government job, for the Attorney General, Whitman worked in "the place where the big southerners now come up to get pardoned-all the rich men \& big officers of the reb army have to get special pardons, before they can buy or sell, or do anything that will stand law."16 By this time, Whitman had attained the grade of Third Class Clerk. More importantly, this position was his first permanent posting. By 1867 , Whitman's salary was $\$ 1,700$ per year, the most money he would earn in his lifetime.

\section{U.S. Patent Office, $8^{\text {th }}$ and F Streets NW. Now the National Portrait Gallery. Whitman worked here from January to June 1865.}

This is one of the few locations in the city associated with Whitman that still stands. Whitman worked in a ground-floor office on the northwest corner of the building, for the Bureau of Indian Affairs. Whitman was fired from this job as part of a larger purge by the Secretary of the Interior, James Harlan. 
10. Department of Justice, Pennsylvania Avenue and Madison Place NW. Now the site of the Treasury Annex. Whitman worked here from 1871 to 1872 .

The Department of Justice was created in 1870 by merging the offices of the Attorney General and the Solicitor of the Treasury. Whitman was among the first group of Justice employees.

\section{U.S. Treasury, $1^{\text {th }}$ and Pennsylvania Avenue NW. Whitman worked here from 1872 to 1873.}

By January 1872, the Department of Justice outgrew its initial building, and Whitman was transferred to the Solicitor's Office in the Treasury Building. This is the only other site on the map that still stands.

\section{Armory Square Hospital, $6^{\text {th }}$ Street and Independence Avenue SE. Now the site of the Smithsonian Institution National Air and Space Museum.}

Wartime Washington had over forty hospitals, and Whitman visited them all. But the one he volunteered in most often was Armory Square, which, because of its proximity to the $6^{\text {th }}$ Street Wharves, often housed the most severely wounded soldiers.

My more detailed essay ("Whitman in Washington") describing Whitman's residences and his associations with Washington, D.C., can be found in the web-based journal Beltway: A Poetry Quarterly, at http://washingtonart.com/ beltway/whitman.html.

Washington, D.C.

KIM RoBERTS

\section{NOTES}

1 Ellen M. Calder, "Personal Recollections of Walt Whitman," Atlantic Monthly (June 1907); reprinted in Whitman in His Own Time, ed. Joel Myerson (Iowa City: University of Iowa Press, 2000), 197.

2 Letter to Martha Whitman, January 2-4, 1863, in Edwin Haviland Miller, ed., Walt Whitman: The Correspondence (New York: New York University Press, 19611977), 1:63; hereafter abbreviated Corr.

3 Letter to Louisa Whitman, June 9, 1863; Corr., 1:108.

4 Letter to Louisa Whitman, October 20, 1863; Corr., 1:168-169.

5 Ibid., 168.

; Letter to Louisa Whitman, June 14, 1864; Corr., 1:233.

Letter to Louisa Whitman, August 24, 1868; Corr., 2:39-40.

Letter to Thomas Jefferson Whitman, January 30, 1865; Corr., 1:250. 
9 Letter to Alfred Pratt, August 26, 1865; Corr., 1:266.

10 Letter to Alfred Pratt, September 27, 1866; Corr., 1:287.

11 Letter to Louisa Whitman, March 5, 1867; Corr., 1:316.

12 Letter to Alfred Pratt, October 28, 1867; Corr., 1:345.

13 Letter to Louisa Whitman, January 22, 1867; Corr., 1:309.

14 Letter to Louisa Whitman, January 31, 1873; Corr., 2:194.

15 Letter to Martha Whitman, January 2, 1863; Corr., 1:62

16 Letter to Alfred Pratt, August 26, 1865; Corr., 1:265.

\section{"GOING TO BED": A RECOVERED WHITMAN ARTICLE FROM THE BROOKLYN DAILY EAGLE}

In the Brooklyn Daily Eagle of December 30, 1847, only weeks before he lost his job as editor, "one of the pleasantest sits" of his life for nearly two years, Walter Whitman published "Going to Bed," a short essay which generally anticipates both Section 11 of "Song of Myself" and "The Sleepers," first published in the 1855 Leaves of Grass. ${ }^{1}$ We can also hear in it an echo of the opium eater's "just-opened lips" ("the parted lips" of sleep) in Section 15 of "Song of Myself." In the voyeuristic passage about the "twenty-ninth bather," Whitman would describe a sexually frustrated Victorian woman who hides "handsome and richly drest aft the blinds of the window" as she looks down on twenty-eight young men bathing naked. In the Eagle essay, Whitman is more decorous in his invasiveness. His object is not "womanly life and all so lonesome," but "a young lady" who is naively sure of herself as a strong candidate for wedlock and its promise of happiness. It is quite possible that on this evening she has enjoyed the "pleasant company" of a suitor and so retires with "some agreeable ideas in her head." Once the light is out, "her fair, delicate form gently presses the couch — and like a dear, innocent lovely creature, as she is, she falls gently into sleep, with a sweet smile on her still sweeter face."

This is not, of course, one of the poet's proto-feminist women who know "how to swim, row, ride, wrestle, shoot, run, strike, retreat, advance, defend themselves" in "A Woman Waits for Me," but more like a character out of a novel of the day. Yet in peering in upon this apparent virgin to the point where her body "gently presses the couch," Whitman exhibits an early interest in going beyond conventional appearances. "Undrape!" he will announce in Leaves of Grass, "you are not guilty to me, nor stale nor discarded, / I see through the broadcloth and gingham whether or no." This future poet sees the naked truth.

The sketch then turns to a man "under the same circumstances" who "acts quite differently." Unlike his "dear, innocent lovely" counterpart, he is described as a "cannibal" whose every move "indicates the coarse, rough mould of his fallen nature." Whereas the female sleeper is something of an angel, he is closer to Shakespeare's Caliban in The Tempest. Or, more locally, he may remind us of the male lover in the underground version of "Once I Pass'd 